DOI: $10.1590 / 1089-6891 v 18 \mathrm{e}-36095$

5.05.00.00-7 MEDICINA VETERINÁRIA

\title{
HEMATOLOGICAL PARAMETERS AND SEROPREVALENCE OF Ehrlichia canis AND Babesia vogeli IN DOGS
}

\section{PARÂMETROS HEMATOLÓGICOS E SOROPREVALÊNCIA DE Ehrlichia canis E Babesia vogeli EM CÃES}

Juliana Pierangeli Fonseca ${ }^{1}$

Fábio Raphael Pascoti Bruhn ${ }^{1}$

Manoel Junqueira Maciel Ribeiro ${ }^{1}$

Christian Hirsch ${ }^{1}$

Christiane Maria Barcelos Magalhães Rocha' ${ }^{1}$

Elizângela Guedes ${ }^{1}$

Antônio Marcos Guimarães ${ }^{1 *}$

${ }^{1}$ Universidade Federal de Lavras, Lavras, MG, Brazil.

*Author for correspondence- amg@dmv.ufla.br

\begin{abstract}
The aim of this study was to determine the prevalence of anti-Ehrlichia canis and anti-Babesia vogeli IgG antibodies in dogs and correlate this prevalence with risk factors to evaluate the relation of serological status to hematological findings. Blood samples of dogs attended from September 2011 to March 2012 at the veterinary hospital of the Federal University of Lavras, Brazil, were analyzed using an indirect fluorescence antibody test (IFAT). Of the total 160 dog serum samples, 23.7\% (38 dogs; $\mathrm{CI}_{95} 17.7 \%$ - 30.7\%) were seropositive for E. canis, $40.0 \%$ (64 dogs; $\left.\mathrm{CI}_{95} 40.0 \%-59.2 \%\right)$ for B. vogeli, and $5.6 \%$ (9 dogs) for both hemoparasites. None of the epidemiological variables showed a significant association $(\mathrm{P}>0.05)$ with seropositivity to $E$. canis and $B$. vogeli. Dogs seropositive for $E$. canis showed lower values for hematocrit $(\mathrm{P}<0.05)$. However, for the erythrogram, the platelet count, the leukogram and clinical signs, no significant difference $(\mathrm{P}>0.05)$ was observed between dogs that were seropositive and seronegative for $E$. canis or for $B$. vogeli. Serological results suggest that infection with $E$. canis and $B$. vogeli is endemic in the canine population in question, with a prevalence of the subclinical phase (asymptomatic) in dogs that are seropositive for ehrlichiosis or babesiosis.
\end{abstract}

Keywords: babesiosis; canine; ehrlichiosis; IFAT; laboratory findings.

\section{Resumo}

O objetivo deste estudo foi determinar a prevalência de anticorpos IgG anti- Ehrlichia canis e antiBabesia vogeli em cães e correlacionar com a prevalência e fatores de risco para avaliar a relação do estado sorológico com os achados hematológicos. Amostras de sangue de cães coletadas de setembro de 2011 a março de 2012, no Hospital Veterinário da Universidade Federal de Lavras, Brasil, foram analisadas usando o teste de reação de imunofluorescência indireta (RIFI). Do total de amostras de soro de 160 cães, 23,7\% (38 cães; IC95 17,7\% - 30,7\%) foram soropositivos para E. canis, 40,0\% (64 cães; IC95 40,0\% - 59,2\%) para B. vogeli, e 5,6\% (9 cães) para os dois hemoparasitas. Nenhuma das variáveis epidemiológicas mostrou associação significativa $(\mathrm{P}>0,05) \mathrm{com}$ a soropositividade para $E$. canis e $B$. vogeli. Cães soropositivos para E. canis mostraram valores médios mais baixos para hematócrito $(\mathrm{P}<0,05)$. No entanto, para o eritrograma, a contagem de plaquetas, o leucograma e os sinais clínicos, nenhuma diferença significativa $(\mathrm{P}>0,05)$ foi observada entre cães soropositivos e soronegativos para E. canis ou para $B$. vogeli. Os resultados sorológicos deste estudo sugerem que a 
infecção por E. canis e B. vogeli é endêmica na população canina em questão, com uma prevalência da fase subclínica (assintomática) em cães soropositivos para erliquiose ou babesiose.

Palavras chave: babesiose; cão; erliquiose; IFAT; parâmetros laboratoriais.

Received on: June $29^{\text {th }}, 2015$

Accepted on: March $4^{\text {th }}, 2016$

\section{Introduction}

Canine monocytic ehrlichiosis (CME) is a disease caused by Ehrlichia canis (Rickettsiales: Anaplasmataceae), a Gram-negative, obligate intracellular bacteria transmitted by the tick vector Rhipicephalus sanguineus, commonly known as the "brown dog tick"(1). Some dogs are asymptomatic, and for others, the clinical manifestations are nonspecific and often involve different systems. Hematological changes during infection are highlighted by thrombocytopenia and leukopenia ${ }^{(2,3)}$. Considered a cosmopolitan disease, CME is particularly prevalent in tropical and subtropical regions, with seroprevalence between 0.7 and $86.2 \%{ }^{(4)}$. In Brazil, the occurrence of canine ehrlichiosis has been increasing significantly in different regions and coincides with the distribution of $R$. sanguineus, which is widely distributed in many urban areas in the country ${ }^{(5)}$.

Canine babesiosis, which is caused by Babesia vogeli (Piroplasmorida: Babesiidae) and transmitted by the tick $R$. sanguineus, is a common disease in tropical areas ${ }^{(1)}$. The disease usually causes fever, lethargy, anorexia, and jaundice, and clinicopathological abnormalities typically found include regenerative immune-mediated hemolytic anemia, nonregenerative anemia, leukocytosis, leucopenia, and thrombocytopenia ${ }^{(6)}$. The seroprevalence of B. vogeli, a cosmopolitan species, ranges from $18.8 \%$ to $73.3 \%{ }^{(7-10)}$.

Knowledge of the prevalence and clinicopathological aspects of vector-borne pathogens that infect dogs at the local and regional level are of epidemiologic interest to veterinary practitioners because it facilitates a prompt diagnosis and appropriate therapy ${ }^{(6)}$. A study on parasitic ectofauna in a canine population in the city of Lavras, Minas Gerais, showed that $R$. sanguineus is the main ectoparasite in urban, indoor dogs ${ }^{(11)}$, and this tick is the vector of $E$. canis and B. vogeli ${ }^{(1)}$. However, despite the importance of ehrlichiosis and babesiosis to veterinary clinical practice, there is no information on the seroprevalence of E. canis and B. vogeli in the population of dogs that are attended at the veterinary hospital in Lavras.

Therefore, this study aimed to determine the prevalence of these canine hemoparasites in dogs (from Minas Gerais State, Brazil) that were attended at the veterinary hospital and correlate the serological status of the dogs with epidemiological variables and hematological findings.

\section{Material and methods}

This study was conducted in Lavras ( $\left.21^{\circ} 14^{\prime} 43 \mathrm{~S} 44^{\circ} 59^{\prime} 59 \mathrm{~W}\right)$, a town located in the southern part of the state of Minas Gerais, from September 2011 to March 2012, and received the approval of Ethics Committee on Animal Use - UFLA (№ 018/2011).

A total of 160 dogs of both sexes and different ages and breeds were attended at the Veterinary Hospital of the Federal University of Lavras (UFLA) and blood samples were collected for convenience, regardless of what motivated the consultation, between September 2011 and March 2012. A tube of blood with anticoagulant (EDTA, 1\%) was collected for a complete hemogram (erythrogram and leucogram) and platelet count, by the automated method, and another tube without anticoagulant for serology. After coagulation, the blood samples to be used for serology were centrifuged at $500 \mathrm{x} \mathrm{g}$ for 10 minutes, and the sera were individually identified and kept frozen in cryotubes at $-20{ }^{\circ} \mathrm{C}$ until undergoing an indirect fluorescent antibody test (IFAT). 
After a dog had undergone clinical examination, the owner responded to a questionnaire about the dog and provided the following data: name, sex, age, breed, origin, type of residence, frequency of acaricide treatments, and current or previous infestation by ticks as noticed by the owner. This information composed the individual record of the animal.

Seroprevalence was determined by the indirect fluorescent antibody test (IFAT), using commercially available IFAT slides that had E. canis (Laboratório Imunodot, Jaboticabal/SP/ Brazil) and B. vogeli-infected dog erythrocytes fixed on them, obtained from a splenectomized dog experimentally infected with an isolate from Lavras/MG, Brazil ${ }^{(12)}$. The antigen of $\mathrm{B}$. vogeli was produced following the methodology described by IICA ${ }^{(13)}$. The IFAT was performed according to Ristic et al. ${ }^{(14)}$ with fluorescein isothiocyanate-conjugated rabbit anti-dog antibody (Sigma-Aldrich, St. Louis, Missouri, USA) diluted at 1:32. Each IFAT slide included a positive and negative control. The evaluation was performed with a fluorescence microscope, and at a dilution of 1:80 (cut-off) was considered seroreactive when there was complete fluorescence of intracellular organisms of E. canis and B. vogeli.

To calculate the true prevalence, and the $95 \%$ confidence interval, we considered the sensitivity (SE) and specificity (SP) of the IFAT was considered for E. canis $(\mathrm{SE}=100 \%, \mathrm{SP}=100 \%)^{(15)}$ and B. vogeli $(\mathrm{SE}=79.2 \%, \mathrm{SP}=100 \%)^{(7)}$ using the EpiTools epidemiological calculators ${ }^{(16)}$. Confidence limits for true prevalence were calculated as described by Reiczigel et al. ${ }^{(17)}$.

To identify the epidemiological factors associated with E. canis and B. vogeli infections in dogs, serological results obtained by IFAT served as the dependent variable, and the variables collected in the interviews were the independent variables in the statistical analysis. Thus, the dependent variable was transformed into binary values (0-negative, 1-positive), and univariate analysis using the chisquare $\left(x^{2}\right)$ test was performed. The variables that showed an association $(\mathrm{P}<0.2)$ according to the $x^{2}$ test or Fisher's Exact test (fewer than five observations were available in at least one cell of the contingency table) were selected for the construction of a logistic multiple regression model. Risk was estimated using an adjusted odds ratio (OR) and a confidence interval of $95 \%$ for the one variable that was significantly associated $(\mathrm{P}<0.05)$ in the logistic regression. The existence of differences in the averages of the results of laboratory tests (complete blood count) between seropositive and seronegative dogs for E. canis and for B. vogeli was verified by parametric Student t-tests.

\section{Results and discussion}

Most of the dogs that were sampled were male $(93 / 160 ; 58.4 \%)$, mixed breed $(86 / 160 ; 54.0 \%)$, adult $(122 / 160 ; 76.4 \%$ were $>1$ year of age), and from households in the urban area of the city of Lavras $(138 / 160 ; 86.3 \%)$. Of the canine serum samples submitted to IFAT, $23.7 \%\left(38 / 160 ;\right.$ IC $_{95}$ : $17.7 \%-30.7 \%$ ) had anti-E. canis antibodies. A similar result was obtained by Trapp et al. ${ }^{(7)}$ in a canine population at a veterinary hospital in Londrina (PR), with $23 \%(87 / 381)$ of the dogs being seropositive for E. canis (IFAT $\geq 80$ ). The results for the city of Lavras (MG) is within the range reported by other studies conducted in Brazil, which have shown that between $14 \%$ and $45 \%$ of the dogs that are attended in veterinary hospitals and clinics are seropositive ${ }^{(18)}$. The frequency of $E$. canis in the serum of dogs in Lavras (MG) was lower than the results observed by Silva et al. ${ }^{(19)}$ in Cuiaba (MT), 42.5\% (108/254; IFAT $\geq 40)$, and by Souza et al. ${ }^{(20)}$ in Salvador (BA), 35.6\% (168/472; IFAT $\geq 80)$. However, Saito et al. ${ }^{(21)}$ observed a prevalence of $4.8 \%(19 / 389$; IFAT $\geq 80)$ in Rio Grande do Sul, which was low compared to that obtained in the present study. Importantly, high prevalence rates reported in some studies may be explained by the use of a sample population with clinical suspicion for $\mathrm{CME}$, increasing the possibility of finding dogs with anti-E. canis antibodies.

The true prevalence of seropositive dogs for $B$. vogeli was $40.0 \%\left(64 / 160 ; \mathrm{IC}_{95} 40.0 \%-59.2 \%\right)$, lower than those previously reported for São Paulo (42.4\%), Belo Horizonte $(66.9 \%)$ and Paraná State $(46.4 \%)^{(4,22,23)}$. Lower seroprevalence data $(35.7 \%)$ were obtained from a population of dogs from a veterinary hospital in the same study area ${ }^{(7)}$. Thus, the results observed in the city of Lavras (MG) for E. canis and B. vogeli are consistent because it is an epidemiologic study where the samples 
were collected for convenience, regardless of what motivated the consultation.

No significant association was observed $(\mathrm{P}>0.05)$ between the serological status of the dogs for $E$. canis and $B$. vogeli and any of the epidemiological variables evaluated. Age and gender was not associated with the risk of seropositivity among the canine population, a finding that is in agreement with most epidemiological studies ${ }^{(23-26)}$. However, in studies with dogs older than one or two years of age, the dogs have a higher frequency of anti- $B$. vogeli antibodies ${ }^{(7)}$ and clinical disease ${ }^{(27)}$. A study evaluating the mode of infection revealed that dogs with only indoor access have a lower frequency $(\mathrm{P}<0.05)$ of infection by E. canis ${ }^{(17)}$, most likely due to the close interaction with their owners. Such close interaction generates a greater zeal for ectoparasite control, and therefore lower parasitism of the dogs by the tick vector ${ }^{(5)}$. At the same time, the presence of infected dogs is not required for $B$. vogeli to remain in the tick population ${ }^{(28)}$, a potential explanation for the higher prevalence of babesiosis. The presence of infected dogs is necessary for the E. canis to remain in a tick population because there is no vertical transmission in ticks ${ }^{(29)}$. B. vogeli, however, can be transmitted transovarially and be passed to the next tick generation even in the absence of infected $\operatorname{dogs} s^{(28)}$.

Regarding the laboratory findings, for the dogs seropositive for E. canis and B. vogeli, there was no significant difference $(\mathrm{P}>0.05)$ in erythrogram and platelet count parameters (Table 1), except that dogs seropositive for $E$. canis showed lower values for hematocrit $(\mathrm{P}<0.016)$ when compared with seronegative dogs. The frequency of dogs with anemia showed no significant association $(\mathrm{P}>0.05)$ with serological status, of the $66(41.2 \%)$ animals with anemia, $18(27.3 \%)$ were seropositive for E. canis, $24(36.4 \%)$ for B. vogeli, and $2(3.0 \%)$ for both hemoparasites. This is likely due to the studied canine population consisting predominantly of asymptomatic dogs, i.e., apparently normal and with no clinical signs suggestive of CME or babesiosis. Thus, the hematological findings were nonspecific, with both anemia and thrombocytopenia being identified in some dogs, but with most values of the erythrogram and the platelet count falling within the normal range for canines. Similarly, 30 dogs examined at the Veterinary Teaching Hospital of the São Paulo State University (UNESP), in Jaboticabal city, Brazil showed no association between the hematological signs (trombocytopenia and anemia; $n=13)$ and serological (IFAT) positive $(n=7)$ or negative $(n=6)$ results $^{(30)}$. In 70 dogs suspected of E. canis infection attended at the Veterinary Hospital of UNESP in Botucatu city, Brazil, 25 anemic PCR-positive dogs did not reveal statistical significance $(\mathrm{P}>0.05)$ when compared with PCR-negative $\operatorname{dogs}{ }^{(3)}$.

Table 1 - Mean and standard deviation of the erythrogram and platelet count parameters according to the serologic status of Ehrlichia canis and Babesia vogeli in dogs $(\mathrm{n}=160)$ attended at the veterinary hospital of the Federal University of Lavras in Minas Gerais State, Brazil

\begin{tabular}{|c|c|c|c|c|c|c|c|}
\hline \multirow{2}{*}{$\begin{array}{c}\text { Hematological } \\
\text { parameters* }\end{array}$} & \multicolumn{3}{|c|}{ Ehrlichia canis } & \multicolumn{3}{|c|}{ Babesia vogeli } & \multirow{2}{*}{$\begin{array}{c}\text { Reference } \\
\text { values } \\
* * *\end{array}$} \\
\hline & $\begin{array}{c}\text { Positive } \\
(\mathrm{n}=38)\end{array}$ & $\begin{array}{l}\text { Negative } \\
(\mathrm{n}=122)\end{array}$ & $\begin{array}{c}p- \\
\text { value }^{\star \star \star}\end{array}$ & $\begin{array}{c}\text { Positive } \\
(n=64)\end{array}$ & $\begin{array}{c}\text { Negative } \\
(n=96)\end{array}$ & $\begin{array}{c}p- \\
\text { value }^{\star *}\end{array}$ & \\
\hline $\begin{array}{l}\text { Red blood cells } \\
\left(\text { million } / \mathrm{mm}^{3}\right)\end{array}$ & $5.23 \pm 1.55$ & $5.80 \pm 1.51$ & 0.055 & $6.80 \pm 1.39$ & $5.58 \pm 1.61$ & 0.400 & $5.5-8.5$ \\
\hline Hematocrit (\%) & $35.09 \pm 11.20$ & $39.97 \pm 10.63$ & 0.016 & $40.12 \pm 10.34$ & $38.06 \pm 1.23$ & 0.247 & $37-55$ \\
\hline $\begin{array}{l}\text { Hemoglobin } \\
\qquad(\mathrm{g} / \mathrm{dL})\end{array}$ & $18.24 \pm 20.99$ & $20.12 \pm 21.64$ & 0.638 & $18.40 \pm 18.87$ & $20.60 \pm 23.13$ & 0.534 & $12-18$ \\
\hline MCV (fL) & $70.15 \pm 6.43$ & $69.87 \pm 6.96$ & 0.827 & $69.79 \pm 6.10$ & $70.16 \pm 7.26$ & 0.743 & $60-77$ \\
\hline $\mathrm{MCH}(\mathrm{pg})$ & $28.47 \pm 17.70$ & $28.96 \pm 18.63$ & 0.884 & $27.52 \pm 16.21$ & $29.80 \pm 19.77$ & 0.451 & $19-24$ \\
\hline $\mathrm{MCHC}(\%)$ & $38.33 \pm 14.78$ & $39.28 \pm 16.11$ & 0.747 & $37.53 \pm 13.52$ & $40.08 \pm 17.16$ & 0.300 & $31-36$ \\
\hline $\begin{array}{l}\text { Platelets } \\
\left(\mathrm{mil} / \mathrm{mm}^{3}\right)\end{array}$ & $180.66 \pm 107.66$ & $201.38 \pm 132.43$ & 0.381 & $196.67 \pm 119.91$ & $199.22 \pm 131.78$ & 0.865 & $200-500$ \\
\hline
\end{tabular}

$\mathrm{MCV}=$ mean corpuscular volume, $\mathrm{MCH}=$ mean corpuscular hemoglobin, $\mathrm{MCHC}=$ mean corpuscular hemoglobin concentration, * Lack of data, normality by Kolgomorov-Smirnov test, **Mann-Whitney Test, *** (31). 
The mechanisms for thrombocytopenia are multi-factorial, representing increased consumption or destruction of platelets and platelet sequestration in the spleen ${ }^{(32)}$. In this study, of the $79(49.1 \%)$ dogs with thrombocytopenia, $20(25.3 \%)$ had anti-E. canis antibodies, $35(44.3 \%)$ had anti-B. vogeli antibodies, and $4(5.1 \%)$ had antibodies for both hemoparasites, indicating that, although it is a characteristic finding, thrombocytopenia is not exclusive to canine ehrlichiosis and may be present in different diseases ${ }^{(18)}$. Thus, those dogs seronegative to $E$. canis and B. vogeli, but with values for hematological parameters and/or the platelet count that are low for canines, are likely infected by other hemoparasites, such as Anaplasma platys and Hepatozoon canis, which are also transmitted by the tick vector $R$. sanguineus ${ }^{(33,34)}$.

Many studies have looked at the prevalence of thrombocytopenia and anemia in dogs with ehrlichiosis and babesiosis. This information is helpful, but from a clinical perspective, it is more important to know how many dogs with anemia or thrombocytopenia have these diseases. Dogs infected with Brazilian strains of $E$. canis consistently develop anemia ${ }^{(35,36)}$, but they may ${ }^{(36)}$ or may not develop thrombocytopenia ${ }^{(35)}$.

Thrombocytopenia is a common finding in dogs with ehrlichiosis ${ }^{(37)}$. In the United States, thrombocytopenia was found in 47 of 61 (77\%) dogs with ehrlichiosis in a retrospective serologic study ${ }^{(38)}$ and in all 30 dogs in a case series ${ }^{(39)}$. In Israel, where ehrlichiosis is more prevalent than in the US, thrombocytopenia was present in 17 of $63(27 \%)$ dogs in a serosurvey ${ }^{(40)}$. In a serologic survey in Switzerland, 20 of 75 (26.7\%) thrombocytopenic dogs seroreacted to E. canis $^{(41)}$. In 49 dogs from Thailand presenting anemia (31 dogs), thrombocytopenia (27 dogs), or fever (5 dogs), 38 (75\%) had antibodies against $E$. canis $^{(42)}$. Differences in prevalence may reflect diversity in strain pathogenicity or be a bias of selection, as thrombocytopenic dogs are more likely to be tested for ehrlichiosis and babesiosis.

We did not evaluate the prevalence of thrombocytopenia in dogs with ehrlichiosis; we verified that approximately $50 \%$ of thrombocytopenic dogs had ehrlichiosis. There is a widespread perception among veterinary practitioners that ehrlichiosis is the main cause of thrombocytopenia in dogs in Brazil. However, Trapp et al. ${ }^{(7)}$ only implicated ehrlichiosis as the potential cause for the thrombocytopenia in one in five dogs, and thrombocytopenia was not more prevalent in dogs seropositive to E. canis than in seronegative $\operatorname{dog} s^{(43)}$.

In the current study, there was no significant difference $(\mathrm{P}>0.05)$ in the leukogram parameters of dogs with or without anti-E. canis and anti-B. vogeli antibodies, with values within the normal range for the canine species. The leukopenia $(26.6 \%)$ and leukocytosis $(26.0 \%)$ frequencies were similar to those frequencies seen in the serological results for these dogs. Importantly, most studies, including the present, one evaluated dogs that were naturally infected by E. canis and B. vogeli without knowing the stage of the disease and disregarding the influence of stress caused by the parasite in the development of secondary changes in the leucogram, which complicates a comparison of the results of the different studies.

According to the study, approximately $25 \%$ of the dogs (40/160) that underwent a clinical examination were infested by ticks at the consultation. Importantly, the rate of tick infestation may be underestimated because clinical veterinarians normally prioritize the viewing of adult forms, neglecting to look for the presence of larvae and nymphs, which are smaller parasitic stages, and consequently, hader to $\operatorname{see}^{(11)}$

Although ticks were not identified in this study, the vector is very likely to be $R$. sanguineus, which is considered the main species observed in dogs bred in urban areas in Brazil ${ }^{(4,5,44)}$. This suspicion is supported because, in this survey in Lavras (MG), there was a predominance of urban indoor dogs $(138 / 160 ; 86 \%)$. According to Guimarães et al. ${ }^{(11)}$, in a study of parasitic ectofauna in 67 urban indoor dogs that were attended at private veterinary clinics in Lavras (MG), R. sanguineus was the only tick species ever observed on animals during clinical examinations.

By this research, there was no significant association $(\mathrm{P}>0.05)$ between ticks being present on an animal during the clinical examination and the serological status of the dog. Most likely, the relatively small number of dogs, in association with the population profile (randomly sampled), explains this 
result. However, it is important to note that $84.2 \%(32 / 38)$ of the dogs that were seropositive for $E$. canis in Lavras (MG) had contact with ticks in the previous 12 months, according to reports from the owners.

Currently, due to changes in lifestyle, dogs are increasingly in contact with humans. In this study, $51.0 \%(82 / 160)$ of owners reported that they dedicate up to seven hours per week of leisure to their dogs, and $21.0 \%(34 / 160)$ more than seven hours a week, thus allowing for exposure to and a potential risk of infestation by the tick $R$. sanguineus. Fourteen owners $(35.0 \%)$, whose dogs had ticks at the consultation time (14/40), also reported having observed ticks attached to their own skin. Among the infested dogs, seven $(7 / 14 ; 50.0 \%)$ animals showed clinical suspicion for CME at the consultation, and four dogs $(4 / 7 ; 57.0 \%)$ were seropositive for E. canis. Despite being considered rare, human infestation with brown dog tick varies regionally, and $R$. sanguineus feeds on humans much more commonly than previously thought ${ }^{(45)}$. In Brazil, there are few studies of parasitism by $R$. sanguineus on humans. Dantas-Torres et al. ${ }^{(46)}$, in the metropolitan area of Recife (PE), described four cases of parasitism on humans by the tick $R$. sanguineus. Louly et al. ${ }^{(47)}$, in Goiania (GO), also reported parasitism of humans by this tick. This fact may suggest that the tick is becoming more anthropophilic or that a more human-adapted population of $R$. sanguineus has been introduced.

Canine monocytic ehrlichiosis (CME) is a major infectious disease that affects dogs and is also of interest in public health due to the recent discoveries of infection by E. canis in humans in Venezuela, where the agent was likely transmitted by the tick vector $R$. sanguineus ${ }^{(48,49)}$. Thus, taking into consideration the concern about the zoonotic potential of $E$. canis and other hemoparasites, further studies on the parasitism of humans by the $R$. sanguineus are necessary.

\section{Conclusion}

In summary, our serological results support the hypothesis that natural infections of $E$. canis and $B$. vogeli in dogs attended at a veterinary hospital in the city of Lavras is common. Positive serologic results in dogs only prove exposure to E. canis and B. vogeli, but not a clinical disease, suggesting that, in the canine population in question, there was a prevalence of subclinical infection (asymptomatic). However, diagnosis of subclinical infections is of great epidemiological importance because infected dogs can serve as reservoirs of infection for other hosts, including humans. Detailed epidemiological surveys using more sensitive and specific methods (e.g., PCR) are needed for the confirmation of infection with $E$. canis and $B$. vogeli and for the determination of co-infection with other tick-borne diseases, whose vector is also the tick $R$. sanguineus.

\section{References}

1. Dantas-Torres F. The brown dog tick, Rhipicephalus sanguineus (Latreille 1806) (Acari: Ixodidae): from taxonomy to control. Parasitology. 2008;152:173-185. http://dx.doi.org/10.1016/j.vetpar.2007.12.030

2. Harrus S, Waner T. Diagnosis of canine monocytotropic ehrlichiosis (Ehrlichia canis): an overwiew. The Veterinary Journal. 2001;187:292-296. http://dx.doi.org/10.1016/j.tvj1.2010.02.001

3. Ueno TEH, Aguiar DM, Pacheco RC, Richtzenhains LJ, Ribeiro MG, Paes AC, Megid J, Labruna MB. Ehrlichia canis em cães 72 atendidos em hospital veterinário de Botucatu, Estado de São Paulo, Brasil. Revista Brasileira de Parasitologia Veterinária. 2009;18:57-61. http://dx.doi.org/10.4322/rbpv.01803010

4. Vieira TSWJ, Vieira RFC, Nascimento DAG, Tamekuni K, Toledo RS, Chandrashekar R, Marcondes M, Biondo AW, Vidotto O. Serosurvey of tick-borne pathogens in dogs from urban and rural areas from Parana State, Brazil. Revista Brasileira de Parasitologia Veterinária. 2013;22:104-109. http://dx.doi.org/10.1590/ S1984-29612013000100019. 
5. Labruna MB, Pereira MC. Carrapatos em cães no Brasil. Clínica Veterinária. 2001;30:24-32.

6. Solano-Gallego L, Baneth G. Babesiosis in dogs and cats - Expanding parasitological and clinical spectra. Veterinary Parasitology. 2011;181:48-60. http://dx.doi.org/10.1016/j.vetpar.2011.04.023

7. Trapp SM, Dagnone AS, Vidotto O, Freire RL, Amude AM, De Morais HS. Seroepidemiology of canine babesiosis and ehrlichiosis in a hospital population. Veterinary Parasitology. 2006;140:223-230. http://dx.doi. org/ doi:10.1016/j.vetpar.2006.03.030

8. Maia MG, Costa RT, Haddad JP, Passos LM, Ribeiro MF. Epidemiological aspects of canine babesiosis in the semiarid area of the state of Minas Gerais, Brazil. Preventive Veterinary Medicine. 2007;79:155-62. http:// dx.doi.org/10.1016/j.prevetmed.2006.11.013

9. Furuta PI, Oliveira TM, Teixeira MC, Rocha AG, Machado RZ, Tinucci-Costa M G. Comparison between a soluble antigen-based ELISA and IFAT in detecting antibodies against Babesia canis in dogs. Revista Brasileira de Parasitologia Veterinária. 2009;18: 41-45. http://dx.doi.org/10.4322/rbpv.01803007

10. Spolidorio MG, Labruna MB, Machado RZ, Moraes-Filho J, Zago AM, Donatele DM, Pinheiro SR, Silveira I, Caliari KM, Yoshinari NH. Survey for tick-borne zoonoses in the state of Espirito Santo, southeastern Brazil. The American Journal of Tropical Medicine and Hygiene. 2010;83:201-206. http://dx.doi.org/ 10.4269/ ajtmh.2010.09-0595

11. Guimarães AM, Lima BS, Rocha CMB. M. Ectofauna parasitária de cães urbanos domiciliados atendidos em clínicas veterinárias particulares na cidade de Lavras, MG, Brasil. Ciência Animal Brasileira. 2011;12:172177. http://dx.doi.org/10.5216/cab.v12i1.8485

12. Guimarães AM, Rocha CMBM, Oliveira TMFS, Rosado IR, Morais LG, Santos RRD. Fatores associados à soropositividade para Babesia, Toxoplasma, Neospora e Leishmania em cães atendidos em nove clínicas veterinárias do município de Lavras, MG. Revista Brasileira de Parasitologia Veterinária. 2009;18:49-53. http://dx.doi.org/10.4322/rbpv.018e1009

13. IICA. Técnicas para el Diagnóstico de Babesiosis y Anaplasmosis Bovinas. Instituto Interamericano de Cooporacion para la Agricultura, San José. Serie Salud Animal. 1984;8. http://repiica.iica.int/docs/B1335E/ B1335E.PDF.

14. Ristic M, David LH, Weisiger RM, Hildebrandt PK, Nyindo MBA. Serological Diagnosis of Tropical Canine Pancytopenia by indirect Immunofluorescence. Infection And Immunity.1972;6:226-231. http://www. ncbi.nlm.nih.gov/pmc/articles/PMC422520/pdf/iai00273-0016.pdf

15. Aguiar DM, Saito TB, Hagiwara MK, Machado RZ, Labruna MB. Diagnóstico sorológico de erliquiose canina com antígeno brasileiro de Ehrlichia canis. Ciência Rural. 2007;37:796-802. http://dx.doi.org/10.1590/ $\underline{\text { S0103-84782007000300030 }}$

16. Sergeant ESG. Epitools epidemiological calculators. AusVet Animal Health Services and Australian

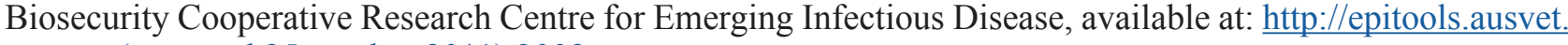
com.au (accessed 25 october 2011).2009.

17. Reiczigel J, Földi J, Ózsvári L. Exact confidence limits for prevalence of a disease with an imperfect diagnostic test. Epidemiology and Infection. 2010;138:1674-1678. http://dx.doi.org/10.1017/S0950268810000385

18. Dagnone AS, Morais HSA, Vidotto MC, Jojima FS, Vidotto O. Ehrlichiosis in anemic, thrombocytopenic, or tick-infested dogs from a hospital population in South Brazil. Veterinary Parasitology. 2003;117:285-290. http://dx.doi.org/ 10.1016/j.vetpar.2003.10.001

19. Silva JN, Almeida ABPF, Boa Sorte EC, Freitas AG, Santos LGF, Aguiar DM, Sousa VRF. Soroprevalência de anticorpos anti-E. canis em cães de Cuiabá, Mato Grosso. Revista Brasileira de Parasitologia Veterinária. 2010;19:108-111. http://dx.doi.org/10.4322/rbpv.01902008

20. Souza, BMPS, Leal DC, Barboza DCPM, Uzêda RS, De Alcântara AC, Ferreira F, Labruna MB, Gondim LFP, Franke CR. Prevalence of ehrlichial infection among dogs and ticks in Northeastern Brazil. Revista 
Brasileira de Parasitologia Veterinária. 2010;19:89-93. http://dx.doi.org/ 10.4322/rbpv.01902004

21. Saito TB, Cunha-Filho NA, Pacheco RC, Ferreira F, Pappen FG, Farias NAR, Larsson CE, Labruna MB. Canine infection by rickettsiae and ehrlichiae in southern Brazil. The American Journal of Tropical Medicine and Hygiene. 2008;79:102-108. Available in http://producao.usp.br/handle/BDPI/1783

22. Dell'Porto A, Oliveira MR, Miguel O. Babesia canis in stray dogs of the city of São Paulo. Comparative studies between the clinical and hematological aspects and indirect fluorescent antibody test. Revista Brasileira de Parasitologia Veterinária.1993;2:37-40.

23. Ribeiro MFB, Passos LMF, Lima JD, Guimarães AM. Frequency of anti-Babesia canis antibodies in dogs, in Belo Horizonte, Minas Gerais. Arquivo Brasileiro de Medicina Veterinária e Zootecnia. 1990;42:511-517.

24. Guimarães AM, Oliveira TMFS, Santa Rosa ICA. Babesiose canina: uma visão dos clínicos veterinários de Minas Gerais. Clínica Veterinária. 2002;8:60-68.

25. Bastos CV, Moreira SM, Passos LM. Retrospective study (1998-2001) on canine babesiosis in Belo Horizonte, Minas Gerais State, Brazil. Annals of the New York Academy of Science.2004;1026:158-160. http://dx.doi.org/10.1196/annals.1307.023

26. Costa-Júnior LM, Ribeiro MFB, Rembeck K, Rabelo EML, Zahler-Rinder M, Hirzmann J, Pfister K, Passos LMF. Canine babesiosis caused by Babesia canis vogeli in rural areas of the State of Minas Gerais, Brazil and factors associated with its seroprevalence. Research in Veterinary Science. 2009;86:257-260. http:/ dx.doi.org/10.1016/j.rvsc.2008.07.002

27. Dantas-Torres F, Figueredo LA. Canine babesiosis: a Brazilian perspective. Veterinary Parasitology. 2006;141:197-203. http://dx.doi.org/ 10.1016/j.vetpar.2006.07.030

28. Taboada J, Merchant SR. Babesiosis of companion animals and man. Veterinary Clinics of North America: Small Animal Practice.1991;21:103-123. http://dx.doi.org/10.1016/S0195-5616(91)50011-5

29. Stich RW, Schaefer JJ, Bremer WG, Needham GR, Jittapalapong S. Host surveys, ixodid tick biology and transmission scenarios as related to the tick-borne pathogen, Ehrlichia canis. Veterinary Parasitology. 2008; 158:256-273. http://dx.doi.org/10.1016/j.vetpar.2008.09.013

30. Nakaghi ACH, Machado RZ, Costa MT, André MR, Baldani CD. Canine ehrlichiosis: clinical, hematological, serological and molecular aspects. Ciência Rural. 2008;38:766-770. http://dx.doi.org/10.1590/ $\underline{\text { S0103-84782008000300027 }}$

31. Jain NC. Essentials of veterinary hematology. $1^{\text {a }}$ ed., Philadelphia: Lea \& Febinger. 1993.

32. Harrus S, Waner T, Aizenberg I, Foley JE, Poland AM., Bark H. Amplification of ehrlichial DNA from dogs 34 months after infection with Ehrlichia canis. Journal of Clinical Microbiology. 1198;36:73-76.

33. Gal A, Harrus S, Arcoh I, Lavy E, Aizenberg I, Mekuzas-Yisaschar Y, Baneth G. Coinfection with multiple tick-borne and intestinal parasites in a 6-week-old dog. Canadian Veterinary Journal. 2007;48:619-22.

34. Hua P, Yuhai M, Shide T, Yang S, Bohai W, Xiangrui C. Canine Ehrlichiosis caused simultaneously by Ehrlichia canis and Ehrlichia platys. Microbiology and Immunology. 2000;44:737-739. http://dx.doi. org/10.1111/j.1348-0421.2000.tb02557.x

35. Macieira DB, Messick JB, Cerqueira AMF, Freire IMA, Linhares GFC, Almeida NKO, Almosny NRP. Prevalence of Ehrlichia canis infection in thrombocytopenic dogs from Rio de Janeiro, Brazil. Veterinary Clinical Pathology. 2008;34:44-48. http://onlinelibrary.wiley.com/doi/10.1111/j.1939-165X.2005.tb00008.x

36. Castro MB, Machado RZ, Aquino LPCT, Alessi AC. Experimental acute canine monocytic ehrlichiosis: clinicopathological and immunopathological findings. Veterinary Parasitology. 2004;119:73-86. http://dx.doi. org/ 10.1016/j.vetpar.2003.10.012.

37. Neer TM, Breitschwerdt EB, Greene RT, Lappin MR. Consensus statement on ehrlichial disease of 
small animals from the infectious disease study group of the ACVIM. Journal of Veterinary International Medicine.2002;16:309-315. http://dx.doi.org/10.1111/j.1939-1676.2002.tb02374.x

38. Frank JR, BreitschwerdtEB. Aretrospective study of ehrlichiosis in 62 dogs from North Carolina and Virginia. Journal of Veterinary International Medicine.1999;13:194-201. http://dx.doi.org/10.1111/j.1939-1676.1999. $\underline{\text { tb02178.x }}$

39. Troy GC, Vulgamott JC, Turnwald GH. Canine ehrlichiosis: a retropective study of 30 naturally occurring cases. Journal of the American Animal Hospital Association.1980;16:181-187.

40. Baneth G, Waner T, Koplah A, Weinstein S, Keysary A. Survey of Ehrlichia canis antibodies among dogs in Israel. Veterinary Record. 1996;138:257-259. http://dx.doi.org/ 10.1136/vr.138.11.257

41. Pusterla N, Pusterla JB, Deplazes P, Wolfensberger C, Muller W, HoraufA, Reusch C, Lutz H. Seroprevalence of Ehrlichia canis and of canine granulocytic Ehrlichia infection in dogs in Switzerland. Journal of Clinical Microbiology.1998;36:3460-3462.

42. Suksawat J, Xuejie Y, Hancock SI, Hegarty BC, Nilkumhang P, Breitschwerdt EB. Serologic and molecular evidence of coinfection with multiple vector-borne pathogens in dogs from Thailand. Journal of Veterinary Internal Medicine. 2001;15:453-462. http://dx.doi.org/ 10.1111/j.1939-1676.2001.tb01574.x

43. De Morais HSA, Dagnone AS, Trapp SM, Gonçalves JSA, Vidotto O. Risk factors in the hemogram of dogs seropositive for Babesia canis and Ehrlichia canis: a hospital population study in South Brazil. Journal of Veterinary Internal Medicine. 2003;17:422-423.http://onlinelibrary.wiley.com/doi/10.1111/j.1939-1676.2003. tb02465.x/epdf

44. Melo ALT, Martins TF, Horta MC, Moraes-Filho J, Pacheco RC, Labruna MB, Aguiar DM. Seroprevalence and risk factors to Ehrlichia spp. and Rickettsia spp. in dogs from the Pantanal Region of Mato Grosso State, Brazil. Ticks and Tick-borne Diseases. 2011;2:213-218. http://dx.doi.org/ 10.1016/j.ttbdis.2011.09.007

45. Harrison BA, Engber BR, Apperson CS. Ticks (Acari:Ixodida) uncommonly found biting humans in North Carolina. Journal Vector Ecology.1997;22:6-12.

46. Dantas-Torres F, Figueredo LA, Brandao-Filho SP. Rhipicephalus sanguineus (Acari: Ixodidae), the brown dog tick, parasitizing humans in Brazil. Revista da Sociedade Brasileira de Medicina Tropical. 2006;39:64-67. http://dx.doi.org/10.1590/S0037-86822006000100012

47. Louly CCB, Fonseca IN, Oliveria VF, Borges LMF. Ocorrência de Rhipicephalus sanguineus em trabalhadores de clínicas veterinárias e canis, no município de Goiânia, GO. Ciência Animal Brasileira. 2006;7:103-106.

48. Stich RW, Schaefer JJ, Bremer WG, Needham GR, Jittapalapon S. Host surveys, ixodid tick biology and transmission scenarios as related to the tick-borne pathogen, Ehrlichia canis. Veterinary Parasitology. 2008;158:256-273. http://dx.doi.org/ 10.1016/j.vetpar.2008.09.013

49. Unver A, Perez M, Orellana N, Huang H, Rikihisa Y. Molecular and antigenic comparison of Ehrlichia canis isolates from dogs, ticks, and a human in Venezuela. Journal of Clinical Microbiology. 2001;39:27882793. http://dx.doi.org/ 10.1128/JCM.39.8.2788-2793.2001 